\title{
A magyarországi munkaerőpiac átalakulásának okai egy hazai empirikus kutatás tükrében
}

\section{Bevezetés}

A korábbi évtizedekben jellemző volt a life-long employment egész életen át tartó - egy cégnél, szervezetnél eltöltött - munkavállalas, amely napjainkra teljesen megváltozott, hasonlóan a munkavállalók munkáltatóhoz való viszonya tekintetében is, és egyre nehezebb feladat a szervezeteken belüli munkaerő megtartása. A HR menedzsereket egyre nagyobb feladat elé állítja a munkaerő megtartása, a fluktuáció csökkentése, a szakképzett munkaerő elérése. Komoly előnyt tudnak szerezni azok szervezetek a versenypiacon, amelyek képesek megszerezni és megtartani az értékes munkaerőt, csökkenteni tudják a fluktuáció nagyságát, nyitottak az innovációk alkalmazására és a robotizáció, automatizáció által kínált lehetőségek kihasználására.

A világon a foglalkoztatás területén különböző tendenciák voltak megfigyelhetők. Az elmúlt közel két évtized során a foglalkoztatás az egész világon növekedett, a 2000-ben regisztrált 2,4 milliárdról 2017re közel 3,4 milliárd före emelkedett (ILO, 2018) a foglalkoztatottak száma. A 2007-2010-es globális pénzügyi válság hatással volt a foglalkozás változására. A növekedés üteme megtorpant és $5,6 \%$-ra lecsökkent, valamint a globális munkanélküliségi mutató megemelkedett 6,3\%-ra. Ha a globális adatokat régiós összehasonlításban vizsgáljuk, megállapítható, hogy Európa nyugati, északi és déli részein a munkanélküliség átlagos mértékének visszaesése a 2007-2010 közötti időszakban magasabb volt, mint a világátlag. Kelet-Európára jellemző, hogy a foglalkoztatottak száma emelkedett a 20012008 közötti időszakban (Kovács et al., 2018), majd a válság idején ez a szám folyamatosan csökkent. Magyarország esetében a 2010-ben begyưrűző válság mintegy 130 ezer munkahely elvesztését eredményezte (Munkaerőpiac, 2019).

Magyarország gazdasági növekedése a 2000-2006 közötti időszakban dinamikus volt, az éves ütem 3,8 és 5,0 százalék között mozgott. Ezen időszakban a magyar gazdaság erőteljesen integrálódott az EU gazdaságához, a külföldi múködő tőke, valamint az előcsatlakozási alapok és a felzárkózást segítő fejlesztési források révén. Ennek ellenére a csatlakozást követően a volt szocialista országok közül leglassabban a magyar gazdaság bővült, növekedési üteme alig haladta meg az EU 28 átlagát. Ez a helyzet a 2012. évi mélypont óta változott, az utóbbi négy évben ismét élénkebb volt a magyar gazdaság növekedése, holtversenyben a 2-5. helyen voltunk a kelet-közép európai országok közötti versenyben (Lengyel-Varga, 2018). A magyar gazdaság növekedési ütemét tekintve a 2017-19-es időszak újra dinamikus bővülést hozott. A GDP korábbi lassulása a várakozásokkal összhangban már 2017 első félévében megállt, s az éves növekedés 4,1\%-ra, majd 2019-re 4,6\%-ra ugrott. A felgyorsult növekedés tovább élezte a magyar és más kelet-európai országok munkaerőpiacainak strukturális problémáit, - ahogy egy másik cikkünkben írtuk - a „pandémiás világválság előtt alig pár hónappal Kelet-Európában (Brixiova et al. 2009; Patricolo, 2019) és hazánkban is „állt a bál” a munkaerőpiacon, dübörgött a munkaerőhiány" (Balogh et al., 2020, 2). Viszont napjainkban a pandémia a GDP erős visszaesését eredményezi mind hazánkban és mind a világ más részein egyaránt (Bagó, 2020).

Az ipari forradalmak nem csak a termelést és a fejlesztést érintik, hanem a munkaerőpiacot és a felsőoktatást is, a technológia fejlődése a történelem során már többször átformálta a munkaerőpiacot. Az ipari forradalom 4.0 óta folyamatosan felmerül a kérdés, hogy ez milyen hatással lesz a munkaerőpiacra és a foglalkoztatáspolitikára. A technológiai fejlődés jelentős mértékben csökkentette a vállalatok termelési költségeit, amely különböző hatással volt és lesz a különböző foglalkoztatási csoportokra. A robotizáció elemzésével és vizsgálatával, továbbá a globális folyamatok értékelésével kaphatunk pontos képet a következő évtizedek munkaerőpiaci változásairól. Ennek tekintetében a munkaerőpiac a megváltozott kihívásokra reagálva más, eltérő struktúrát, új 
munkakörnyezetet, munkakultúrát, kompetenciákat igényel. A munkaerőpiaci igényváltozásra egyértelmúen reagálnia kell és fel kell készülnie, amennyiben hatékonyan, a humán tőke számára is fenntarthatóan kíván múködni. Az igények változásának folyamata már érzékelhető a húzóágazatokban, mind a munkaadók, mind a munkavállalók oldaláról tekintve egyaránt (Bostrom, 2014; Poór et al, 2020).

\section{Munkaerőpiac Magyarországon}

A technológiai fejlődés gyökeresen meg fogja változtatni a munkaerőpiacot, hiszen a megszűnő munkahelyek helyébe újak fognak lépni, a technológiai innovációk megszüntették a kommunikáció és a földrajzi határok miatt korábban kialakult korlátokat. Ennek hatására előtérbe került az atipikus foglalkoztatási formák térnyerése, hiszen a munkánk bárhonnan elvégezhető, a megszokottól eltérő munkaidőben. A legnagyobb kihívásnak az tekinthető a munkaerőpiac számára, hogy a változások miatt megszűnő munkahelyek és az újonnan születő munkahelyek egyensúlya tartható lesz-e, azaz a munkaerőpiac mérlege egyensúlyi állapotba fog-e kerülni (Harari, 2018). Az egyik lehetséges megoldás az innováció felgyorsítása lehet, emellett fontos az iskolai képzettség szintjének emelése, mivel a technológiai fejlődés szükségessé teszi a magasan képzett szakemberek alkalmazását. Lehetséges megoldás a munkaerőpiac átalakulásának támogatására az állami beavatkozások hatásosabbá tétele és a vállalkozói szféra felélénkítése. (Bőgel, 2013).

A technológiai változás mindig maga után vonja a munkaerőpiac változását, amely korunk legnagyobb munkaerőpiaci kihívása, és további kérdés hogy miként fog reagálni ezekre a változásokra a munkaerőpiac. Ez a változás új készséget és képességet fog megkövetelni a munkaerőpiacon, amely hatására növekszik az átképzések száma. A magyarországi munkaerőpiac egyik nagy problémája a szakképzetlen munkaerő magas létszáma, valamint a munkaerőpiac azon szereplői is nagy kihívást tartogatnak, akiknek magasabb elvárásai vannak a munkahelyükkel kapcsolatban. A megszúnő munkahelyek a foglalkoztatásra is hatással lesznek, ahol átrendeződés figyelhető meg, mely változások a képzettebb munkavállalók számára lesznek előnyösek. (Csugány, 2018).

A foglalkoztatáspolitikai szempontból a technológiai fejlődésnek köszönhetően változott a munkavégzés időtartama, mely rugalmasabb munkavégzést tesz lehetővé, valamint egyre népszerübbek a részmunkaidős képzések. Generációs tekintetben jellemzően a fiatalabb korosztályba tartozó munkaerő részesíti előnyben a megváltozott munkaidőkeretet. A változások azonban nem csak a munkaidőkeretet érintették, hanem a munkavégzés helyét is. Korábban nagy hangsúly volt a munka és magánélet szétválasztásának, a munkavégzést a munkahelyükhöz kötötték. A rugalmas foglalkoztatási forma elsődleges célja a hatékonyabb és kreatív munkavégzés volt azáltal, hogy optimalizálják a munkaerőforrás kihasználását. Előnyként említhető, hogy a foglalkoztatás költsége is jelentősen csökkenthető. Mivel ez a típusú foglalkoztatás olcsóbb, így a munkavállalóknak a kieső rést pótolni kell. Jellemzően a fiatalabb korosztályhoz áll legközelebb ez a fajta munkavégzés, hiszen ők már ebben a digitális világban nőttek fel. Hátrányai közé sorolható, hogy az emberi kapcsolatok a háttérbe szorulnak, mivel nem igényel személyes kapcsolatokat. (Csoba, 2018).

A munkaerőhiány kihívást jelent az ország számára, mivel a technológia nem pótolja az adott betöltetlen állások betöltését, miközben a munkaerőhiány által érintett munkahelyek által generálható értékteremtés hiánya rést eredményezhet a termelésben, szolgáltatásban. Az OECD jelentése szerint az EU-n belül 80 millió munkavállaló szenved az eltérő képesítések miatt (Eurostatistics, 2020). Az eltérő képesítések abban nyilvánulnak meg, hogy az adott munkavállaló vagy alul-, vagy felülképzett. A munkaerőhiányos gazdasági területek a legutóbbi felmérések szerint a high-tech, építkezés, vendéglátás, szolgáltatás, szállítmányozás, IT területét sújtották.

Magyarországon a foglalkoztatottak számának növekedésében fontos szerepet játszik a munkaerőpiaci folyamatok javulása, a közfoglalkoztatás kiterjesztése, a nyugdíjkorhatár folyamatos emelése, valamint az inaktív népességet érintő célzott foglalkoztatási intézkedések (pl. gyermekgondozási ellátás melletti munkavállalás elősegítése) egyaránt. A javuló munkaerőpiaci mutatók mellett az elmúlt 
években egyaránt mérséklődött a tartósan, legalább egy éve munkanélküliek aránya, valamint az álláskereséssel eltöltött idő hossza. A munkanélküliség által leginkább a fiatalabb generációhoz tartozók érintettek: a 15-24 évesek munkanélküliségi rátája a korcsoportok között hosszú évek óta kimagasló, jóllehet folyamatosan mérséklődő irányzatú.

A lakossági jövedelmek szoros kapcsolatban állnak a nemzetgazdaság mindenkori helyzetével. A reálkeresetek gyors ütemben nőttek az ezredforduló utáni években, majd a költségvetési expanziót követő egyensúlyjavító intézkedések és a 2008-as gazdasági válság következtében vásárlóerejük csökkent, majd 2013-tól a gazdasági konjunktúra és az adójogszabályok változása következtében újra emelkedni kezdtek a bérek.

\section{1. ábra Foglalkoztatási ráta alakulása az elmúlt 25 évben, százalékban}

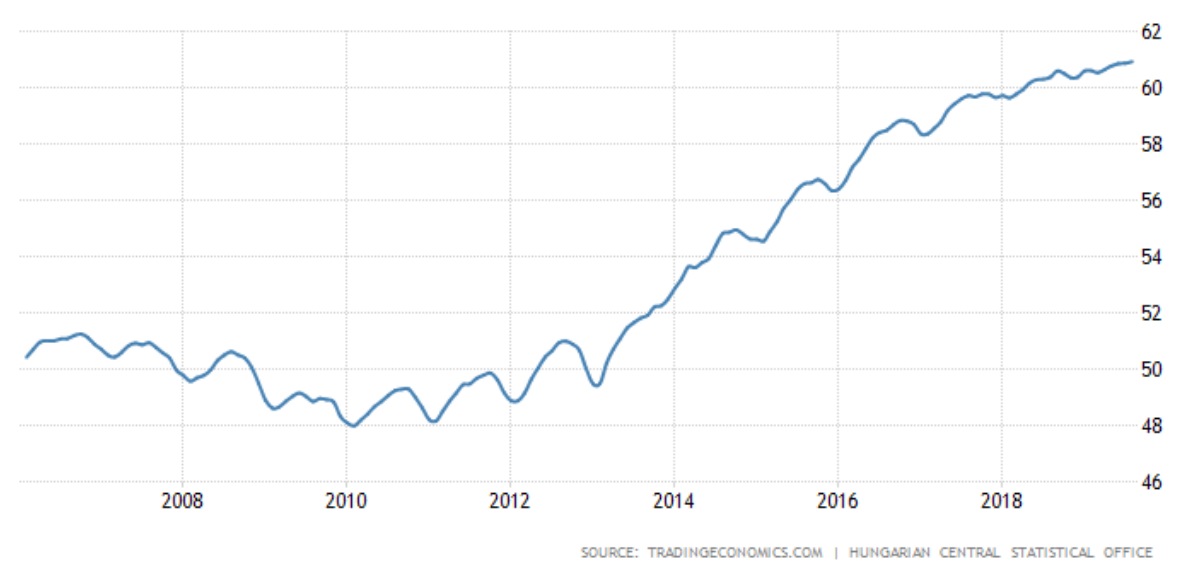

Forrás: KSH, 2019

A kormányzati intézkedések közül a minimálbér és a garantált bérminimum emelése jelentősen befolyásolta mind a verseny-, mind a közszféra kereset alakulását.

\section{Fluktuáció}

A szervezet számára nem minden esetben lehetséges a megfelelő összetételű és minőségű humánerőforrás biztosítása, amely egy vállalkozás életében erős veszélyforrást jelent (Koncz, 2004). A magas fluktuáció számos kihívás elé állítja a szervezetek vezetőit, melynek legfőképp gazdasági hatásai vannak, azaz számos költséggel járhat (Chen, Lin, Lien, 2011). A fluktuáció mértéke iparáganként és földrajzi területenként is nagyon eltérő mértéket mutat.

A humán menedzsment területén a fluktuáció alatt a munkaerő vándorlását, a dolgozók munkahelyváltoztatását, a munkahely elhagyását értjük. A munkahelyváltásnak nem csak külső okai lehetnek, hanem különböző belső okokra is visszavezethető, azonban elmondható, hogy bizonyos nagyságú fluktuáció szükséges a megfelelő motiváltság fenntartásához, illetve az új ötletek szempontjából egészséges dolog a „vérfrissítés”. A fluktuáció egy adott időszakon belül a vállalatnál a megszúnt munkaviszonyok számát, illetve ennek a jelenségnek százalékos kimutatott arányát mutatja meg, a fluktuáció az egyik legfontosabb teljesítménymutató. A fluktuációs mutató növekedése azonnal felhívja a vezetők figyelmét az egyes problémákra, hibákra, amely problémák hosszú távon gátolhatják a szervezet sikeres és eredményes múködését. Ennek tudatában a fluktuációra a szervezeten belül komoly figyelmet kell fordítani, illetve adott esetben ezt a jelenséget befolyásolni (Munkajog, 2016; Staw, 1980).

A fluktuáció különböző mértékben jelenik meg a szervezetek életében, amelyekre eltérő magyarázatai vannak és minden szervezet életében problémát és komoly költséget jelent. Igaz, hogy bizonyos esetekben a fluktuáció pozitívan is befolyásolja a vállalat múködését (Boudreau; 2010). A nemzetközi vállalatoknál alkalmazott gyakorlat a fluktuáció mesterséges szinten tartása, amely biztosítja a vállalat számára a korszerű tudás, a friss új gondolatok és az új szemléletek bekerülését (Nemeskéri-Pataki, 2007). Az alacsony szinten tartott fluktuáció esetében a szervezetek, a célegyezőség elve alapján olyan 
tevékenységek elvégzésére törekednek, amelyek ösztönzik a munkavállalókat a saját érdekeinek és a vállalat érdekeinek összeegyeztetésére (Govindarajan et al., 2009). Napjainkban számos tanulmány foglalkozik a kedvezőtlen munkahelyi fluktuáció és a leadership közti összefüggések problémakörével, amelyekben felhívják a figyelmet arra, hogy a vezetőknek jelentős szerepe lehet a kedvezőtlen munkahelyi fluktuáció kialakulásában. Hom és szerzőtársai (2017) a munkaerő fluktuáció globális problematikájára hívta fel a figyelmet tanulmányában, mely szerint az alkalmazottak egyre magabiztosabban állnak készen a jelenlegi munkahelyük elhagyására és ez a tendencia a jövőben várhatóan tovább fog emelkedni, amely okán sürgős kormányzati beavatkozásokra lesz szükség a magas munkahelyi fluktuációból eredő gazdasági károk enyhítésére.

Mathis és Meglich (2014) tanulmányában a fluktuációt a szervezetek költségesnek tartják, a munkaerő pótlás a kilépő alkalmazott fizetésének akár az 50-60\%-át is elérheti (Allen, 2008).

Keszthelyi (2016) szerint a legmagasabb fluktuáció az úgynevezett „kék gallérosok”, jellemzően a fizikai dolgozók között figyelhető meg, a vállalkozások közel 10\%-ánál a kilépők aránya meghaladja a 40\%-ot és a vállalkozások közel 13\%-a szerint a fluktuáció mértéke $20-40 \%$ közé tehető. A fluktuáció nagyságára a szervezeteknél lévő nyitott pozíciók és a munkanélküliségi ráta is hatással van. A munkahelyi fluktuáció többféle okra vezethető vissza. Ilyen például a munkahelyi elégedetlenség, az alacsony lojalitás mind a munkáltató, mind a munkavállaló irányába, a munka-magánélet egyensúly konfliktusa és természetesen a bérezés (Csedő et al., 2016). Mathis-Meglich (2014) megállapítása szerint, amikor csökken a munkanélküliségi ráta, vele fordítottan arányosan nő a fluktuáció.

A fluktuáció mutatójának optimális mértékét nehéz meghatározni és ellene nehéz bármit is tenni, hiszen egyrészről természetes folyamat, másrészről rengeteg külső ok játszik közre a kialakulásában.

Összességében elmondható, hogy a fluktuációnak vannak negatív és pozitív hatásai a szervezet múködésére. A negatív hatásokat egyértelműen a szervezetet elhagyók és a helyettük érkező új alkalmazottakkal kapcsolatos költségek jelentik, és a szervezet számára a régi munkaerővel együtt járó értékes tudás és képességek elvesztése, különösen abban az esetben problémás, ha a távozó alkalmazott ezeket a képességeket, tapasztalatokat a konkurenciánál kamatoztatja. Ezzel szemben pozitív hatásként értékelhető, hogy a fluktuációval bekövetkezhet a motiválatlan, nem jól teljesítő munkavállalók távozása, ami viszont jó irányban befolyásolhatja a szervezet teljesítményét. A fluktuáció kezelésére a kutatók eltérő viselkedési modelleket állítanak fel, de mostanáig még nem sikerült olyat felállítani, ami tökéletesen múködött volna annak köszönhetően, hogy az emberi viselkedés és döntési mechanizmus egy nagyon összetett folyamat (Susskind-Susskind, 2015).

\section{Robotizáció}

Az ipari forradalom kibontakozása James Watt nevéhez fúződik, aki 1769-ben megalkotta a gőzgépet, és ezzel kezdetét vette az első ipari forradalom. A második ipari forradalom korában a termelés jellemzően gyártósorokon történt, melyek elektromos hajtással múködtek, leginkább szabványosított alkatrészeket, szerszámgépeket gyártottak. A harmadik ipari forradalomban már megjelentek a számítógépek, mellyel kezdetét vette az automatizáció. Az ipari forradalom 4.0 a mesterséges intelligencia megjelenését eredményezte. Az ipari forradalmakra összességében elmondható, hogy céljuk a gyorsabb, pontosabb, hatékonyabb és kedvező költségeken történő gyártás volt. Az ipari forradalom 5.0 az ember és robot közti hatékony együttmúködésre fókuszál, jelentős figyelmet fordítva a környezettudatosságra. $A$ robotok képesek a tömeggyártásra, az emberi tervezés pedig egyedi termékek és szolgáltatások megalkotására. Amennyiben ez a kettő párosítható, lehetőség nyílik ezen egyedi termékek tömeggyártására. A robot és ember közti hatékony együttmúködés eloszlatja azon félelmeinket, hogy szükség lesz-e a munkára, ha az kiváltható lenne a digitalizációval (Dervenkár, 2018).

Az ipari forradalom kapcsán megállapítható, hogy a gépekhez fúződő viszonyunk gyökeresen megváltozott, mely egyben feszültséget is generál. Erre mutat rá Némethy és Poór (2019) szerzőtársak az ipari forradalom 5.0 kapcsán folytatott kutatásában. Úgy vélik, hogy a vállalatok versenyképességét leginkább a munkaerőköltség határozza meg. Ez a munkaerőköltség a robotok megjelenésének 
következtében jelentős változáson ment keresztül. Az értékesített robotok száma évről évre emelkedik. Ez alól a 2009-es év képez kivételt, ahol közel felére csökkent az értékesített robotok száma. Az előrejelzések ugyanezt a tendenciát valószínűsítik a jövőben is. (Némethy- Poór, 2019)

2. ábra Az értékesített robotok száma földrészenként 2015-2020,

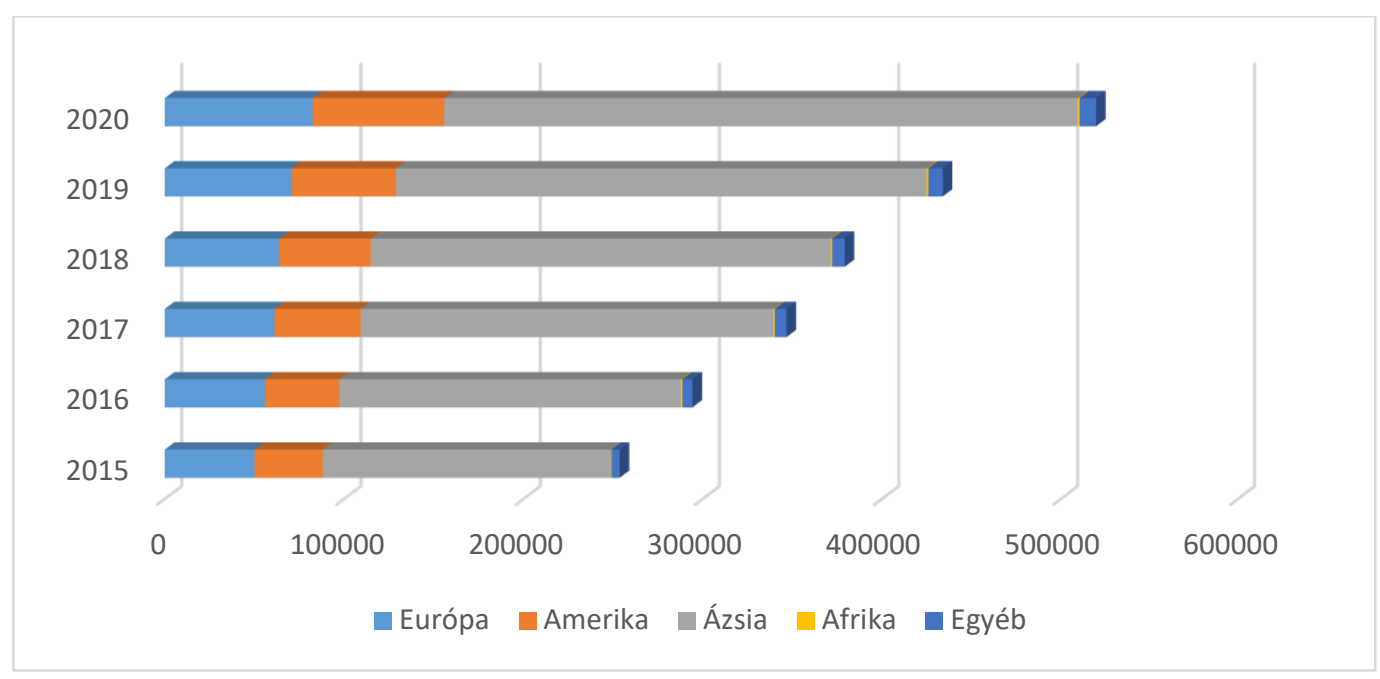

Forrás: Nemzetközi Robotika Szövetség 2017-es statisztikai adatai és elörejelzése alapján a szerzők saját szerkesztése.

A földrészenként történő vizsgálatból megállapítható, hogy Ázsiában értékesítették a legtöbb robotot 2010 és 2020 között. Ázsiát Európa követi a rangsorban, míg Amerika áll a dobogó harmadik fokán. Az afrikai és egyéb földrészek esetében pedig még nem jelentős a robotok jelenléte.

A 10.000 munkavállalóra vetített ipari robotok számát tekintve a vizsgálatuk az alábbiakat mutatta ki. Európai viszonylatban Németország vezeti a rangsort. Kína a 10.000 munkavállalóra vetített listában a világátlagot tekintve már nem szerepel az élen. Együttesen vizsgálva az eladások és a felhasználások számát, Dél- Korea, Japán és Németország vezeti a rangsort. Magyarország helyezése meglepő a 10.000 munkavállalóra vetített 2016-os rangsorban, mivel nem sokkal marad le Kínától, illetve az Egyesült Királyságtól, megelőzve Oroszországot, Norvégiát, Lengyelországot és Indiát. A statisztikai adatok alapján elmondható, hogy azon országok, ahol az exportban jelentős bevételt jelent a robotgyártás és értékesítés, még nem feltétlenül jelenti azt, hogy az adott ország a robotok felhasználásában is az élen jár. A robotizáció csökkenő tendenciát eredményez a költségek tekintetében, mely kedvező hatást gyakorol a kis- és középvállalkozások számára. (Némethy-Poór, 2019)

\section{Kutatás módszertana}

A kutatásunk tárgyát képező munkaerőhiány, a munkaerő megtartás vagy annak hosszabb távú megoldását segítő robotizáció olyan kérdések, amelyekre egyaránt érvényesek az előzőleg felvetett megoldások. Empirikus vizsgálatunk alapvetően ex-post (Usunier at al., 2017) jellegű, azaz a megfigyelési időszak tényadataira támaszkodva vizsgáltuk a munkaerőhiánnyal és munkaerő megtartással, valamint a robotizációval kapcsolatos gyakorlatot Magyarországra vonatkozóan. A kérdőív a statisztikai elemzések megkönnyítése érdekében legtöbb esetben zárt kérdéseket alkalmaz. A vizsgált témaköröket nagymértékben lefedő, előre megfogalmazott válaszok közül a legjellemzőbbek megjelölését kértük a válaszadóktól, a fluktuációval és munkaerőhiánnyal kapcsolatosan, a munkaerő megtartás és a robotizáció összefüggésében.

A kutatás alapján azt feltételezzük, hogy a fluktuáció a fizikai dolgozók tekintetében a legmagasabb arányú és ezeket a pozíciókat lehet a legnehezebben betölteni, a munkaerőhiány elsősorban a szakképzett munkaerő hiányára vezethető vissza, a robotizáció megoldás lehet a fluktuációra. 


\section{Kutatási eredmények}

A cikkben jelzett vizsgálatunkat 2019-ben bonyolítottuk le (Poór et al., 2020). A kutatásban összesen 277 szervezet (vállalat és intézmény) vett részt, a vizsgált minta tulajdonformák szerinti megoszlása alapján megállapítható, hogy a hazai magántulajdon volt a legnagyobb részarányban (43,3\%) az összes válaszadó között. A legkisebb arányban a hazai köztulajdonú forma (17,5\%) és vegyes tulajdoni forma $(3,2 \%)$ volt. Ágazati megoszlást tekintve a legtöbb válaszadó az iparból, 91 fő $(36,3 \%)$ a szolgáltatási szektorból 48 fő $(19,1 \%)$ és kereskedelmi ágazatokból 30 fő (12\%) volt.

A vizsgált minta tulajdonformák szerinti megoszlása alapján megállapítható, hogy a hazai magántulajdon volt a legnagyobb részarányban $(43,3 \%)$ az összes válaszadó között. A legkisebb arányban a hazai köztulajdonú forma $(17,5 \%)$ és vegyes tulajdoni forma $(3,2 \%)$ volt.

A minta méret és létszám adatai alapján elmondható, hogy a kérdőívet kitöltők közül a legnagyobb arány az 1.000 fő feletti szervezetekből $(27,4 \%)$ került ki, míg a legkisebb arányt $(8,3 \%)$ az 501-1.000 fő közötti mérettel rendelkező szervezeteket képviselők tették ki. Ezenfelül nagy arányban $(17,9 \%)$ szerepeltek még a kérdőívet kitöltők között a 10-50 közötti létszámú szervezeteket képviselők, vagyis a kis- és középvállalkozásokban dolgozók.

1. táblázat: Méret - létszám megoszlása (\%)

\begin{tabular}{|c|c|c|}
\hline Létszám & $\mathbf{N}$ & $\%$ \\
\hline $\mathbf{2 - 9}$ fö között & 32 & 12,7 \\
\hline $\mathbf{1 0 - 5 0}$ fö között & 45 & 17,9 \\
\hline $\mathbf{5 1 - 1 0 0 ~ f o ̈ ~ k o ̈ z o ̈ t t ~}$ & 24 & 9,5 \\
\hline $\mathbf{1 0 1 - 2 5 0 ~ f o ̈ ~ k o ̈ z o ̈ t t ~}$ & 38 & 15,1 \\
\hline $\mathbf{2 5 1 - 5 0 0 ~ f o ̈ ~ k o ̈ z o ̈ t t ~}$ & 23 & 9,1 \\
\hline $\mathbf{5 0 1 - 1 0 0 0 ~ f o ̈ ~ k o ̈ z o ̈ t t ~}$ & 21 & $\mathbf{2 1}, 3$ \\
\hline $\mathbf{1 . 0 0 0 ~ f o ̈ ~ f e l e t t ~}$ & 69 & 100,0 \\
\hline Összesen & 252 & \\
\hline Hiányzó & 25 & \\
\hline Összeg & 277 & \\
\hline
\end{tabular}

Forrás: a szerzők saját szerkesztése

Az árbevétel-költség alakulásokat figyelembe véve elmondható, hogy a kérdőívet kitöltők közül jelentős hányadot képviseltek a 3 és 30 millió euró árbevétellel rendelkező szervezetek, a kérdőívet kitöltőknek mintegy 26,3\%-át adva. Emellett nem elhanyagolható az a tény sem, hogy a 300 millió euró feletti árbevétellel rendelkezett a kérdőívünket kitöltők 20\%-a. Míg a legkisebb árbevételt realizáló szervezetek közül is 5,4\%-os volt a kitöltési arány.

\section{A fluktuáció helyzete, gyakorisága}

A fluktuációt elemezve megállapítható, hogy a vizsgált szervezetek esetében a felső- és középvezetőknél tapasztalható a legkisebb arányú fluktuáció, míg a legnagyobb, 40 százalékos fluktuáció a fizikai dolgozókat jellemzi leginkább. Ha az átlag (6-10\%-os) fluktuációs arányt nézzük, akkor az összes szervezet esetében 52 főt érintett a vizsgált időszakban, felső- és középvezetők közül 20 fő, felsőfokú szakvégzettségúeknél 46 fő, értékesítők esetében 30 fő, adminisztratív dolgozókból 43 és a fizikai állományból pedig 44 fő volt érintett a fluktuációban a vizsgált szervezetek esetében. 
2. táblázat: Fluktuáció gyakorisága (\%)

\begin{tabular}{|c|c|c|c|c|c|c|c|}
\hline Jellemzők & $\mathbf{0 \%}$ & $\mathbf{0 - 5 \%}$ & $\mathbf{6 - 1 0 \%}$ & $\mathbf{1 1 - 2 0 \%}$ & $\mathbf{2 1 \% - 4 0 \%}$ & $\mathbf{4 0 \%}$ & Összesen \\
\hline Szervezet összesen & 12 & 56 & 52 & 54 & $\mathbf{2 9}$ & 9 & 212 \\
\hline Felsó- és középvezetók & 99 & $\mathbf{7 3}$ & $\mathbf{2 0}$ & $\mathbf{8}$ & $\mathbf{4}$ & 5 & 209 \\
\hline Felsőfokú végzettségú szakemberek & 58 & $\mathbf{7 5}$ & 46 & 16 & 10 & 1 & 206 \\
\hline Értékesítők & 69 & 45 & 30 & 19 & 10 & 6 & 179 \\
\hline Adminisztratív dolgozók & 50 & 79 & 43 & 21 & 11 & 3 & 207 \\
\hline Fizikai dolgozók & 44 & 39 & 44 & 38 & 23 & 16 & 204 \\
\hline
\end{tabular}

Forrás: a szerzők saját szerkesztése

A nehezen betölthető álláshelyek sorrendiségére a következőt kaptuk, kiindulva a válaszadók adataiból: első helyen szerepel a fizikai dolgozó, melyet 79 válaszadó jelölt meg, mint nehezen betölthető munkahely, ezután következik a mérnök (45 fö), értékesítő (24 fő), ezt követi az adminisztrátor (14 fő). Míg a válaszadók adataiból az is kiderült, hogy melyek azon munkakörök, melyeket viszonylag könnyebben be lehet töltetni, holtversenyben 1 fő jelölte meg az asszisztens, beszerző, egészségügyi, építőipari, logisztikai, rendőr és tanácsadói munkaköröket.

\section{3. táblázat: Nehezen betölthető munkakörök (N,\%)}

\begin{tabular}{|c|c|c|}
\hline Munkakörök & $\mathbf{N}$ & $\%$ \\
\hline Adminisztráció & 14 & 6,5 \\
\hline Asszisztens & 1 & 0,5 \\
\hline Beszerző & 1 & 0,5 \\
\hline Egészségügy & 1 & 0,5 \\
\hline Építőipar & 1 & 0,5 \\
\hline Értékesítő & 24 & 11,1 \\
\hline Felsőfokú végzettségú & 3 & 1,4 \\
\hline Felsővezető & 9 & 4,1 \\
\hline Fizikai munkás & 79 & 36,4 \\
\hline Könyvelő & 5 & 2,3 \\
\hline Logisztika & 1 & 0,5 \\
\hline Mérnök & 45 & 20,7 \\
\hline Pénzügy & 8 & 3,7 \\
\hline Projektvezető & 4 & 1,8 \\
\hline Rendőr & 1 & 0,5 \\
\hline Soför & 8 & 3,7 \\
\hline Tanácsadó & 1 & 0,5 \\
\hline Tanár & 2 & 0,9 \\
\hline Technikus & 5 & 2,3 \\
\hline Vezető & 4 & 1,8 \\
\hline Összesen & 217 & 100,0 \\
\hline
\end{tabular}


A kapott eredményeink alapján, Magyarországon átlagosan 10,03 hétig tart egy üres munkakör betöltése.

\section{A munkaerőhiány kialakulásához vezető okok}

A kutatás során vizsgáltuk, hogy milyen okokra vezethető vissza a munkaerőhiány kialakulása. E kérdés esetében több ok is meg volt jelölve elöre, melyekröl a válaszadók dönthettek, hogy milyen részarányban tekintik mérvadónak az egyes munkakörök esetében.

A versenytársak konkurenciája elsősorban a felsőfokú végzettségűekre és a fizikai pozíciókban lévők hiányára jelent okot. A túl alacsony bérek miatt adminisztratív és fizikai állományban jelentkeznek hiányok. A szakképzetlen munkaerő hiánya elsősorban a fizikai állományt érinti. A külföldi elvándorlás miatt jelentkező munkaerőhiány a felsőfokú végzettségúek és a fizikai dolgozók esetében jelentős probléma. A gazdasági növekedéssel együtt elsősorban az adminisztratív és fizikai dolgozók esetében csökkent a munkanélküliek száma. A csökkenő népesség elsősorban a fizikai állomány hiányára van kihatással. Az oktatási rendszerből adódó munkaerőhiány esetében a felsőfokú végzettségűek és a fizikai állomány esetében tapasztalható negatív tendencia. A rossz munkakörülmények és a közlekedési infrastruktúra problémái a fizikai dolgozókat érintik leginkább. A munka és magánélet összehangolása a fizikai és a felsőfokú végzettséggel rendelkezők esetében jelent problémát.

4. táblázat: A munkaerőhiány kialakulásához vezető okok (Átlag)

(Kérjük, értékelje az egyes okok elöfordulását az adott munkakörök esetében 1=egyáltalán nem jellemző és 5=nagyon jellemző!)

\begin{tabular}{|c|c|c|c|c|}
\hline Okok & $\begin{array}{c}\text { Felsőfokú } \\
\text { végzettségú } \\
\text { szakemberek }\end{array}$ & Értékesítök & $\begin{array}{c}\text { Adminisztratív } \\
\text { dolgozók }\end{array}$ & $\begin{array}{c}\text { Fizikai } \\
\text { dolgozók }\end{array}$ \\
\hline Versenytársak konkurenciája & 3,16 & 2,6 & 2,91 & 3,17 \\
\hline Túl alacsony bérek & 2,81 & 2,48 & 2,89 & 3,26 \\
\hline Szakképzett munkaerő hiánya & 2,90 & 2,38 & 2,48 & 3,08 \\
\hline Külföldi elvándorlás & 2,48 & 2,05 & 2,02 & 2,74 \\
\hline $\begin{array}{c}\text { Gazdasági növekedés miatt } \\
\text { kevesebb munkanélküli }\end{array}$ & 2,18 & 1,88 & 2,26 & 2,53 \\
\hline $\begin{array}{c}\text { Csökkenő népesség miatt } \\
\text { kevesebb munkaképes személy }\end{array}$ & 1,90 & 1,88 & 1,90 & 2,32 \\
\hline $\begin{array}{c}\text { Oktatási rendszer problémái } \\
\text { Rossz munkakörülmények }\end{array}$ & 2,51 & 2,05 & 2,32 & 2,52 \\
\hline $\begin{array}{c}\text { A közlekedési infrastruktúra } \\
\text { hiányosságai (munkahely nehéz } \\
\text { megközelíthetősége) }\end{array}$ & 1,68 & 1,71 & 1,77 & 2,22 \\
\hline $\begin{array}{c}\text { Munka és magánélet } \\
\text { összehangolásának nehézségei }\end{array}$ & 2,26 & 2,06 & 2,12 & 2,49 \\
\hline
\end{tabular}

Forrás: a szerzők saját szerkesztése 
A válaszadó szervezetek véleménye szerint az 5 leginkább hatásos eszköz a munkaerőhiány kezelésére a versenyképes bérezés, a tiszta és átlátható teljesítményértékelés, a rugalmas munkaidő alkalmazása, a munkavégzési körülmények javítása és a kulcsemberek megtartása.

5. táblázat: Az alkalmazott 5 leghatékonyabb eszköz

\begin{tabular}{|c|c|}
\hline 1. & Versenyképes bérezési, fizetési rendszer \\
\hline 2. & Teljesítményértékelési és prémiumrendszer \\
\hline 3. & Rugalmas munkaidő alkalmazása \\
\hline 4. & Munkavégzési körülmények javítása \\
\hline 5. & Kulcsember megtartási program \\
\hline
\end{tabular}

Forrás: a szerzők saját szerkesztése

A kormányzati megoldások közül, figyelve a sorrendiségre, a következő eszközöket tartjuk hatékonynak: bértámogatási rendszer fejlesztése, lakhatási támogatások, közlekedés fejlesztése, vállalati bölcsődék és óvodák fejlesztése, és az atipikus foglalkoztatási formák szélesebb elterjedése.

6. táblázat: Kormányzati megoldások a munkaerőhiány kezelésére (5 legsikeresebb)

\begin{tabular}{|c|c|}
\hline 1. & Bértámogatási rendszer kiterjesztése \\
\hline 2. & Lakhatási támogatások \\
\hline 3. & Közlekedés fejlesztése, munkába járási hozzájárulás \\
\hline 4. & Vállalati bölcsődék és óvodák támogatása \\
\hline 5. & Atipikus foglalkoztatási formák \\
\hline
\end{tabular}

Forrás: a szerzők saját szerkesztése

\section{Robotok alkalmazása}

A munkaerőhiány kezelésére új és modern megoldásként szolgálhat az ipari robotok elterjedése. Ennek vizsgálatára is kiterjedt a kutatásunk. A vizsgálataink eredménye szerint a leghatékonyabb eszköz lehet a jövőben a fluktuáció megoldására, és a munkaerő pótlására a robotizáció. Kiemelendő viszont az a tény is, hogy a válaszadók a robotizációt még nagyon költséges megoldásnak tartják, valamint kérdéses, hogy mennyire tudnak majd a robotok az emberekkel együtt dolgozni.

7. táblázat: A munkaerőhiány enyhitésére milyen robotizációs eszközök lehetnek a leghatékonyabbak (Átlag)

(Kérjük, írja be a rangsorokat: 1-5 a gazdaságilag leghatékonyabb megoldáshoz 1 = a leghatékonyabb rendszer, 5 - a legkevésbé hatékony!)

\begin{tabular}{|l|l|}
\hline & Átlag \\
\hline Bizonyos munkafolyamatok a robotok alkalmazásával megbízhatóbban végrehajthatók. & 2,32 \\
\hline A robotizáció képes felváltani a monoton munkafolyamatokat (pl. futószalag mellett végzett emberi munka). & 2,10 \\
\hline A robotok alkalmazása kiváltja az emberi szervezetre káros emberi munkavégzést. & 2,39 \\
\hline A robotizáció költségei magasak, csak hosszabb távon térülnek meg. & 2,84 \\
\hline A robotizáció megoldás lehet a fluktuációra. & 3,08 \\
\hline A robotok és az emberi munkaerő képes együtt dolgozni. & 2,63 \\
\hline A robotizált technológia a jövőben munkatársként fog funkcionálni. & 3,03 \\
\hline
\end{tabular}

Forrás: a szerzők saját szerkesztése 
A kiértékelt kérdőívek alapján elmondható, hogy a vizsgált mintában 143 esetben nem alkalmaztak robotot munkavégzésére, míg 20 feletti robottal a vizsgált szervezetek 12,2\%-a rendelkezett, a legtöbb esetben $(14,5 \%)$ a 2-5 robotot jelölték meg a válaszadók.

8. táblázat: Robotok száma ( $\mathrm{N}, \%)$

\begin{tabular}{|c|c|c|c|c|c|c|}
\hline & \multicolumn{5}{|c|}{ Robotok száma az Önök szervezeténél? } & \multirow{2}{*}{ Összesen } \\
\hline & Nincs & $\mathbf{1}$ & $\mathbf{2 - 5}$ & $\mathbf{6 - 2 0}$ & $\mathbf{2 0}$ felett & 221 \\
\hline $\mathbf{N}$ & 143 & 4 & 32 & 15 & 27 & $100,00 \%$ \\
\hline$\%$ & $64,70 \%$ & $1,80 \%$ & $14,50 \%$ & $6,80 \%$ & $12,20 \%$ & \\
\hline
\end{tabular}

Az alkalmazott robotok jelentős része ipari robot $(61 \mathrm{db})$ volt, míg szerviz robot $9 \mathrm{db}$ szerepelt a mintában.

9. táblázat: Alkalmazott robotok típusainak megoszlása (N,\%)

\begin{tabular}{|c|c|c|c|}
\hline & \multicolumn{2}{|c|}{ Ipari robot } & \multirow{2}{*}{ Összesen } \\
\hline & Nem & Igen & 277 \\
\hline $\mathbf{N}$ & 216 & 61 & $100,00 \%$ \\
\hline
\end{tabular}

\begin{tabular}{|c|c|c|c|}
\hline \multirow{2}{*}{} & \multicolumn{2}{|c|}{ Szerviz robot } & \multirow{2}{*}{ Összesen } \\
\cline { 2 - 4 } & Nem & Igen & 277 \\
\hline $\mathbf{N}$ & 268 & 9 & $100,00 \%$ \\
\hline$\%$ & $96,80 \%$ & $3,20 \%$ & \\
\hline
\end{tabular}

Forrás: a szerzők saját szerkesztése

A válaszadók átlagosan 3,71 ponttal értékelték, vagyis erősen közepesen azt, hogy hasznosak a robotok a munkahelyeken.

A jövőbeli tervekre kapott válaszokból viszont egyértelmúen kiderül, hogy a válaszadók 44,7\%-a elutasítja az effajta modern megoldást, és a válaszadók csupán 4,3\%-a támogatja teljes egészében 1 éven belül az ez irányú fejlesztéseket. A válaszadók 23,4\%-a 1-5 éves intervallumot jelölt meg a jövőbeli tervekre az ez irányú fejlesztésekre vonatkozóan.

\section{Összefoglalás}

Az elmúlt évtizedekben a hazai munkaerőpiacot nagyon sok hazai és nemzetközi tényező befolyásolta, amely következtében jelentős változáson ment keresztül. A gazdasági válságot végigkísérő nagyarányú munkanélküliség csökkenését követően, munkaerőhiány lépett fel számos iparágban, melynek okai között kell említeni a munkaerőmobilitást, az európai bérkülönbségeket, és a technológia gyors iramú fejlődését, amely napjainkra megváltozott a koronavírus megjelenésének köszönhetően. A szemünk előtt aktuálisan kibontakozó koronavírus válság azonban alapjaiban változtatja meg a piaci körülményeket, várhatóan az európai növekedés, és a globális növekedés gátjává válik az elkövetkező néhány év folyamán.

Cikkünk az európai munkaerőpiaci felmérésünk Magyarországra vonatkozó válaszait elemzi, a magyar minta összesen 277 értékelhető kérdőívet tartalmaz, amelyek segítségével válaszokat kaphatunk 
Magyarország munkaerőpiacán tevékenykedő hazai és külföldi vállalatok/vállalkozások munkaerőpiaci kihívásaival kapcsolatban. A mintavétel a 2019-es évben került lebonyolításra, a világjárvány okozta új kihívások még nem jelentek meg a kitöltők válaszaiban.

A Magyarországon múködő szervezetek legnagyobb kihívása a munkaerőpiaccal összefüggésben a munkaerő megtartása, és új tehetségek megtalálása és bevonzása. A humánerőforrás szervezés szempontjából komoly problémaként jelentkezik a munkaerő megtartása, amely nemcsak a magasan képzett, illetve speciális tudással rendelkező szakemberek esetére vonatkozik, hanem az összes munkakör tekintetében jelen van. A kutatási eredmények rámutatnak, hogy a munkaerő megtartásának kulcsfontosságú eszköze a versenyképes bérezés, azonban a jó fizetés még nem elégséges megtartó erő az aktuális versenykörnyezetben. Mindezekre a problémákra a válaszadók legnagyobb hányada szerint a teljesítményértékelés és a teljesítményalapú prémiumrendszer bevezetése lehet a megfelelő válasz, továbbá egy sor egyéb eszköz és körülmény is biztosítja, hogy egy vállalkozás képes legyen lojalitást kiváltani a meglévő és potenciális új munkavállalókból. A kutatási eredmények rámutatnak, hogy a kellemes és biztonságos munkakörnyezet, a kellemes légkör, az otthoni munkavégzés lehetősége ma már elengedhetetlen feltételei a cég zavartalan múködésének. $A$ munkaerőhiány és a szúkösen rendelkezésre álló munkaerő akár a növekedés gátjaként is jelen van egyes iparágakban és az előttünk álló időszak új kihívásokat és újfajta körülményeket teremt majd a hazai és nemzetközi piacokon egyaránt.

A szerzők egy, a múlt évben végzett kutatásuk eredményeit mutatták be. A tanulmányban megfogalmazott feltételezéseket, miszerint a fluktuáció a fizikai dolgozók tekintetében a legmagasabb arányú és ezeket a pozíciókat lehet a legnehezebben betölteni, a munkaerőhiány elsősorban a szakképzett munkaerő hiányára vezethető vissza és a robotizáció megoldás lehet a fluktuációra, a szerzők elfogadták.

A kutatási eredményeket a szerzők három vállalati jellemző dimenziójában elemezték. Az eredmények alapján megállapítható volt, hogy számos esetben hatással van a munkaerőhiány kialakulására a szervezeti méret, a tulajdonosi szerkezet és a vállalat árbevétele. A szervezetek ezekkel az okokkal tisztában vannak és lépéseket tesznek a dolgozók megtartása érdekében, amelyek hosszú távon enyhíthetik a vállalatok munkaerőhiány problémáit. A robotizáció és az automatizáció megoldás lehet a monoton munkafolyamatok területén kialakult munkaerőhiány problémakörére.

\section{Felhasznált szakirodalom}

- Allen, G. D. (2008): Retaining Talent. SHRM Foundation, United States of America, http://www.shrm.org/about/foundation/research/documents/retaining\% 20talent\%20final.pdf. pp.1-24. (Letöltés: 2017.10.07.)

- Bagó J. (2020): Járvány és munka. Új Munkaügyi Szemle, 1. (3.), pp.14-25.

- Balogh G. - Király Zs. - Kópházi A. - Kun A. I. - Poór J. (2020): A magyarországi országos KoronaHR kutatási projekt céljai, módszerei és első tapasztalatai. 1. (4.), pp. 2-7.

- Bostrom N. (2014): Superintelligence: Paths, Dangers, Strategies, Oxford University Press 2014, ISBN: 9780199678112, (Letöltve: 2018. 02.26.)

- Boudreau, J.W. (2010): Retooling HR. Harvard Business Press, Boston.

- Bőgel, G., 2013. Technológiai fejlődés és munkaerőpiac: A mai kor tényleg más?. Munkaügyi szemle , (6.), pp. 9-19.

- Brixiova, Z. - Li, W. - Yousef, T. (2009): Skill shortages and labor market outcomes in Central Europe. Economic Systems, 33 (1.), pp. 45-59.

- Chen, M. F.- Lin, C. P. -Lien, G. Y. (2011): Modeling job stress as a mediating role in predicting turnover intention. The Service Industries Journal, 31 (8), pp.1327-1345.

- Csedő Cs. - Frajna-Piller A. - Horváth A. - Kolbe T. - Kovács T. - Poór J. (2016): Szakemberhiány és munkaerőmegtartás kulcsmunkakörökben 2016. Menedzsment és HR Kutató Központ, Szent István Egyetem-Pivot Capital, Budapest 
- Csoba, J., (2018): Flexibilitás a munkaerőpiaco. A munkavállalók szociális biztonságának ugródeszkája, vagy zsákutcája?. Munkaügyi Szemle 61. (6). 7-20.

- Csugány, J., (2018): A technológiai változások hatása a munkapiacra: új kivívások és lehetőségek. Taylor Gazdálkodás- és Szervezéstudományi Folyóirat 4.szám (No.34), pp. 2636.

- Dervenkár, I., (2018): Mindig van feljebb: egyesek már Ipar 5.0-ról beszélnek https://bitport.hu/mindig-van-feljebb-egyesek-mar-ipar-5-0-rol-beszelnek (Letöltés 2020.10.18.)

- Eurostatistics. Data for short-term analysis (2020): Luxembourg: Publications Office of the European Union. 04/2020, 1-100. https://ec.europa.eu/eurostat/documents/3217494/10712680/KS-BJ-20-004-ENN.pdf/8c987277-7d47-dac4-6ff1-fd7c43ea4a28 (Letöltés: 2020.11. 15.)

- Ford, M. (2016): Robotok kora. HVG könyvek, Budapest,

- Govindarajan, V.-Immelt, J.R.-Trimble, C. (2009): How GE is disputing itself Harvvard Business Review, 87 (10). pp. 50-56.

- Harari, N. Y. (2018): 21 lessons for the 21st century. Johnatan Cape, London.

- Hom, P. W., - Lee, T.W., - Shaw, J.D. - Hauskneckt, J.P. (2017): One hundred years of employee turnover theory and research. Journal of Applied Psychology, 102, pp. 530-545.

- ILO (2018): World Employment and Social Outlook: Trends 2017. International Labour Office, Geneve.

- International Robotics Federation https://ifr.org/ifr-press-releases/news/robot-investmentreaches-record-16.5-billion-usd (Letöltés: 2019.08.30)

- Keszthelyi, C (2016): Hungary suffers labor shortage in many sectors, Budapest Business Journal, September 2 - September 15, pp. 15

- KSH (2019): Foglalkoztatási ráta alakulása https://www.ksh.hu/stadat eves 21 (Letöltés:2019. 06. 18.)

- Kovács I. É. - Karoliny M-né - Nemeskéri Zs. (2018): A létszámváltozások és kezelésük gyakorlata, az atipikus foglalkoztatási formák, munkaviszonytípusok használata. In: Poór J.Karoliny M-né.- Kovács I. É.-Illés B.Cs. (Szerk.): A HR gyakorlata - Hasonló és eltérő jellemzők az emberi erőforrás menedzsment globális, regionális és hazai gyakorlatának alakulásában. Wolters Kluwer, Budapest

- Koncz K. (2004): Kompetencia alapú személyügyi tervezés. In: Humán erőforrások gazdaságtana. Bíbor Kiadó. Miskolc.

- Lengyel I.-Varga A. (2018): A magyar gazdasági növekedés térbeli korlátai - helyzetkép és alapvető dilemmák. Közgazdasági Szemle, LXV. (5.), pp. 499-524.

- Mathis, J. V.- Meglich,V. (2014): Human Resource Management, Cengage Learning, New York.

- Munkaerőpiaci helyzetkép, 2014-2018. (2019): KSH, Budapest. http://www.ksh.hu/docs/hun/xftp/idoszaki/munkerohelyz/munkerohelyz17.pdf (Letöltés: 2020. 05. 5.)

- Munkajog (2016): A fluktuáció. https://szakszervezetek.hu/dokumentumok/munkajog/6427a-fluktuacio. (Letöltés: 2020.11.20)

- Némethy, K., - Poór , J. (2019.). A jövő munkahelye az ipar 5.0 küszöbén. http://munkaugyiszemle.hu/jovo-munkahelye-az-ipar-50-kuszoben (Letöltés: 2020.11.18

- Nemeskéri Gy. - Pataki Cs. (2007): A HR gyakorlata. Ergofit Kft., Budapest.

- Patricolo, C. (2019): Czech Republic looks east to ease labour shortages. https://emergingeurope.com/news/czech-republic-looks-east-to-ease-labour-shortages/(Letöltés: 2020.01.05)

- Poór J.- Antalik I.- Karácsony P.- Allen, D. E. (Szerk.) (2020): Munkaerőpiaci trendek és tendenciák Kelet-Közép Európa országaiban. (Kutatási monográfia) Selye János Egyetem, Komárno.

- Staw, B. M. (1980): The consequences of turnover. Journal of occupational behavior, 1, pp. 253-273.

- Susskind, R. - Susskind, D. (2015): The Future of the Professions: how technology will transform the work of human experts. Oxford University Press, Oxford. 